\title{
The Effect of Mangrove on Fish Catch Using Belat at Teluk Pemedas and Sanipah of Kutai Kartanegara Regency, East Kalimantan Province, Indonesia
}

\author{
Bustam Sulaiman ${ }^{1,5^{*}}$, Azis Nur Bambang ${ }^{1,2,3}$, Hartuti Purnaweni ${ }^{1,3,4}$, Mohammad Lutfi $^{6}$ \\ ${ }^{1}$ Doctoral Program of Environmental Science, School of Postgraduate Studies, Diponegoro University, Semarang-Indonesia \\ ${ }^{2}$ Faculty of Fishery and Ocean, Diponegoro University, Semarang, 50275, Indonesia \\ ${ }^{3}$ Master Program of Environmental Science, School of Post Graduate Studies, Diponegoro University, Semarang, 50275, Indonesia \\ ${ }^{4}$ Faculty of Social Science and Political Science, Diponegoro University, Semarang, 50275, Indonesia \\ ${ }^{5}$ Department of Oil and Gas Processing Engineering, STT MIGAS, Balikpapan, 76127, Indonesia \\ ${ }^{6}$ Department of Petroleum Engineering, STT MIGAS, Balikpapan, 76127, Indonesia
}

\begin{abstract}
The increasing population at Teluk Pemedas and Sanipah coastal areas of Kutai Kartanegara Regency, East Kalimantan Province, has led to coastal degradation. The problem was mainly caused by conversion of mangrove into aquaculture, agriculture, plantation industrial, and residential areas. This research was a study case, used descriptive analys is to describe the local fishermen activity using belat traditional device to catch fish. The results revealed that there were many fishermen still did not know the benefits of mangrove for economy growth, ecological, ecotourism etc. This condition affects to the decline of the mangrove function. Fisherman who used belat often move from one location to another location in order to find places that have many catches. The belat which are placed in good environment mangrove areas produces lots of catches that greatly benefit the fisherman, therefore mangrove ecosystem must be well preserved for the sustainability of fishermen's efforts to earn a living.
\end{abstract}

\section{Introduction}

Coastal area is an area with a very dynamic environment condition compared to other locations in the world [1]. Coastal area development in Indonesia has been challenged by various problems such as high rate of local poverty, low and minimum infrastructure quality, and high rate of coastal degradation including degradation of its mangrove area [2]. This case also occurred in Teluk Pemedes and Sanipah, coastal areas of Kutai Kertanegara Regency, East Kalimantan Province.

Mangrove areas at Teluk Pemedas and Sanipah have been experience degradation due to the natural phenomenom and human activities such as the conversion to aquaculture and settlements. Mangrove forest contributes large spectra of ecosystem services. Its environmental functions include nutrition supply and regeneration, pollutant recycle, water cycle and quality preservation [3]. In three decades Indonesia has lost 40\% of its mangroves, mainly as a result of aquaculture development. Annual mangrove deforestation in Indonesia is only $6 \%$ of its total forest loss. The lost of mangrove forest also contributes to $42 \%$ of gas emission which cause a greenhouse effect due to the destruction of coastal ecosystem. The prevention of mangrove deforestation in Indonesia is believed to fulfill a quarter of $26 \%$ target of the emission reduction by 2020 [4].
Mangrove forest plays an important role to reduce wave energy and mangroves height can potentially reduce associated damage. All evidence suggests that mangroves can reduce the height of wind and swell waves over relatively short distances. wave height can be reduced by between 13 and $66 \%$ over $100 \mathrm{~m}$ of mangroves [5]. Early warning system in coastal areas can be built by considering numerical modeling of hydrodynamics [6] and mangrove condition based on the satellite imagery. Mangrove can also reduce disaster due to hydrometeorological activity resulted from climate change, such as greater maximum tides and rising sea level, so that the cost for building the flood control can be reduced [7].

The socio-economic values of mangrove are varied. It can be useful for many purposes such as for building material, fire wood, fishing scheme, port, railway, furniture to handicraft and colouring materials [8].

Mangrove has a great potential for social and economic development in coastal area and especially for the fishermen, therefore, mangrove should be well planned for its sustainability. Ecological function of mangrove forest is beneficial for among others provide nutrition to aquatic biota and nursery ground for various biota, shelter for abrasion, typhoon attack, and tsunami, ocean water prevention, and waste absorber [9]. 
Mangrove ecosystem ecologically acts as nutrition provider, nursery ground and feeding ground, coastal and erosion protection, and nursery and feeding for fish species and crustacea, sea water intrusion and natural disasters, such as tsunami and typhoon. It also functions as mangrove seeding area [10-13].

The other benefit of the mangrove system is also to promote the effort and plan for ecotourism because mangrove is very important for ecotourism sustainable development and improvement of local community life [14].

The actual benefits of the mangrove system also deals with social and cultural functions. Mangrove forest supports religious and spiritual values, in addition to aesthetic and recreation for the ecotourism, therefore, community participation is expected in the ecotourism planning because it is important towards the ecotourism sustainable development and in fulfilling the social and economic equilllibrium of ecotourism $[15,16]$.

Mangrove ecosystem provide sound area for catching fish among the fishermen, especially for fishermen in Teluk Pemedas and Sanipah who make use of belat, a traditional fishing net popular among the local fishermen.

This research aims to describe the benefit of belat for the fishermen of Teluk Pemedas and Sanipah, who usually place the belat in the mangrove area.

\section{Method}

This study was conducted at Teluk Pemedas and Sanipah, Samboja District, Kutai Kartanegara Regency, East Kalimantan Province, Indonesia. The study applied a case study, an approach to learning, explaining, and interpreting a case in its natural context without any external intervention. The case study used in this study was intrinsic due to the fact that the phenomenon of mangrove forest in a replicated manner that has caused degradation of the coastal area.

The research used an analytical-descriptive manner for comprehending descriptive effort of phenomena found during the study. The case study research model can also meant a report of particular event, situation, or development constructed in a comprehensive and detailed manner. The phenomena found in this study were fishermen activities who used belat, a local, unique fishermen's device for catching fish. The selection of this case study was based on the questions of how and why of a phenomenon as well as of intensive, in-depth, detailed, and comprehensive case assessment.

This study restricted and focused on the effects of mangrove on the catches of the fishermen who used belat in the research area. This study applied a descriptive method using interviews as data collection instrument. The samples (event, human, situation) were expected to provide information.

The interviews were directed to local people that could provide representative data. The local community consist of fishermen and community leaders from which reliable information about the functions of mangrove forest and belat could be obtained.
The recapitulation data of population at Teluk Pemedas and Sanipah are presented in Table 1.

Table 1. Number of Population 2017

\begin{tabular}{|l|l|l|l|l|l|}
\hline No. & Village & Household & M & F & Total \\
\hline 1 & $\begin{array}{l}\text { Teluk } \\
\text { Pemedas }\end{array}$ & 791 & 1447 & 1376 & 2823 \\
\hline 2 & Sanipah & 2311 & 2931 & 2152 & 5083 \\
\hline
\end{tabular}

This study used a purposive sampling to get particular objective of the research with desirable research outputs. The purposive sampling technique requires research subjects to represent the population being examined.

Sampling was determined by Slovin [18] equation as follow:

$$
n=\frac{N}{1+N e^{2}}
$$

$n=$ sample size

$N=$ population size

$e=$ percent of tolerated or preferable errors due to sample miscollection, e.g. $(=0.1)$

The population size (Table 1) resulted in 97 samples from Teluk Pemedas and 98 samples from Sanipah.

Table 2. Number of respondents at Teluk Pemedas

\begin{tabular}{|l|c|c|c|}
\hline Occupation & Total & $\mathbf{\%}$ & Respondent \\
\hline Civil servants & 71 & 11,95 & 11 \\
\hline Private employees & 321 & 54,04 & 52 \\
\hline Entrepreneurs & 84 & 14,14 & 14 \\
\hline Farmers & 37 & 6,23 & 6 \\
\hline Fishermen & 34 & 5,72 & 6 \\
\hline Service providers & 47 & 7,91 & 8 \\
\hline
\end{tabular}

Source: Monograph of Teluk Pemedas Village 2017

Tabel 3. Number of respondents at Sanipah

\begin{tabular}{|l|c|c|c|}
\hline Occupation & Total & \% & Respondent \\
\hline Civil servants & 106 & 4,76 & 5 \\
\hline $\begin{array}{l}\text { Private } \\
\text { employees }\end{array}$ & 755 & 33,93 & 33 \\
\hline Entrepreneurs & 266 & 11,96 & 12 \\
\hline Farmers & 595 & 26,74 & 26 \\
\hline Fishermen & 266 & 11,96 & 12 \\
\hline $\begin{array}{l}\text { Service } \\
\text { providers }\end{array}$ & 237 & 10,65 & 10 \\
\hline
\end{tabular}

Source: Monograph of Sanipah Village 2017

\section{Results and discussions}

Belat (Barrier Trap) is a kind of trap for catching fish, usually placed at tidal areas. It consist of two nets as walls and a kind of "bag" between the two nets. The fishermen usually place these nets in a V or $U$ shape in the inner mangrove areas during maximum high tide and draw the nets during low tidal wave in which the fish were trapped in the bag. The picture of belat is as follows : 


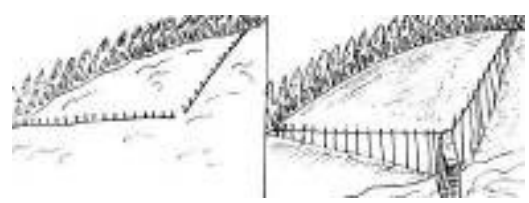

Fig 1. Belat (Barrier Trap) [17]

The respondents were the local fishermen of Teluk Pemedas and Sanipah. The observation revealed that fishermen who used belat had the larger number of catches around the mangrove area than that of away from the mangrove area. Mangrove ecosystem significantly proved that it is home of many fish, enabling the fishermen able to find good catch using traditional fish catch device of belat.

The belat fishermen proved that their economic life was adequate, proved by their belongings of motorcycles and/or cars, television, and good furniture in their house, to mention some.

In additional to being belat fishermen, these local people also had side-jobs such as working in the plantation (cocoa, rubber, etc.) in their leisure times. The average income of the belat fishermen provided that they earned income from vary occupations, are more than earned by civil servants, private employees, farmers, entrepreneurs, and service provider. The following graphic illustrations and tables compare the proportion of the income.

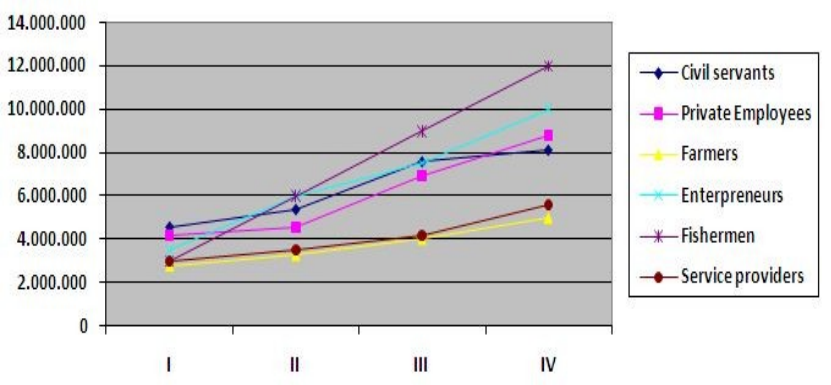

Fig. 2. Income comparison in Indonesian Rupiah (IDR) of belat fishermen by occupation at Teluk Pemedas.

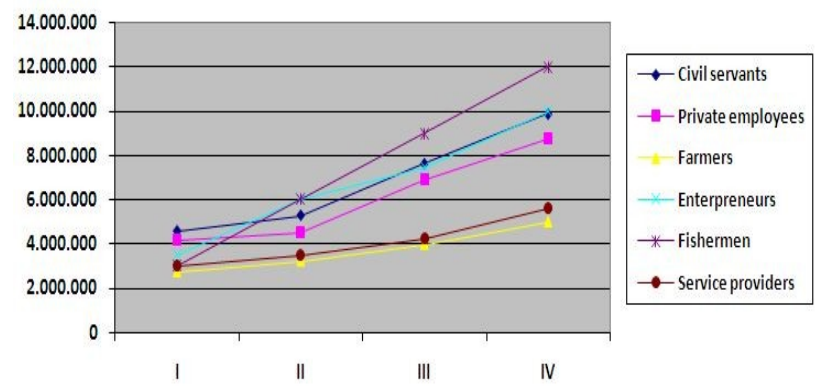

Fig. 3. Income comparison in Indonesian Rupiah (IDR) of belat fishermen by occupation at Sanipah.

The fisherman often moved their belat from one location to another in order to find places that have many catches. The average income of belat fishermen was Rp. 3.000.000/belat. Whereas belat ownership varied from one to four units per fisherman. The fishermen informed that belat was one of the most practical techniques because they do not need to wait too long to catch the fishes, it needs only one-day process. Their income had been adequate to meet their family's day-to-day need. Furthermore, there is no negative effect of the existence of the belat to the mangrove ecosystem because they used their belat at tidal areas adjacent to the mangroves. Their knowledge about the benefits of mangrove forest was satisfactory, even though more efforts should be taken to get them more informed towards the sustainability of the mangrove forest.

\section{Conclusions}

The belat which are placed at good environment of mangrove areas produces lots of catches. The fisherman able to routinely catch good amount of fish, enabling them have the average income around Rp. 3.000.000 per belat/day. The fisherman used belat very effectively and efficiently just by simply utilizing tidal zone in shallow water around their settlements to earn a good living. Good mangrove proved to be very beneficial for the fishermen

According to the results, there are several recommendations to preserve the mangrove forest in this research location, namely:

1. Coastal community should manage and preserve mangrove for its sustainability. It must become a mutual responsibility.

2. Mangrove ecosystem had been well preserved. Belat did not have adverse impact on the ecosystem and provided larg number of catches to the fishermen.

3. Concerted evaluation of the damaged mangrove site is necessary to restore and flourish its existence.

4. The government is expected to make a continued socialization of the role and benefit of the mangrove forest for its sustainability.

5. There must be a synergy between the government and the citizens towards sustainable mangrove.

\section{References}

1. M. A. Marfa'i, Quaestiones Geographicae 31 (3), 2012, pp 47-55.

2. H. Purnaweni, Kismartini, S.P. Hadi, T. R. Soeprobowati. Advance Science Letter. 23 (3), March 2017, pp. 2582-2583 https://doi.org/10.1166/asl.2017.8711

3. H. J. Ruitenbeek. Ecological economics, 10, 3 (1994), pp. 233-247

4. D. Murdiyarso, J. Purbopuspito, J. Kauffman, J.B. Warren, M.W. Sasmito, S.D. Donato, D.C. Manuri, S. Krisnawati, H. Taberina, S. Kurnianto. Nature Climate Change 5, pp. 1089-1092 (2015). Doi: $10.1038 /$ nclimate 2734

5. A. L. McIvor, L. Möller, T. Spencer, M. Spalding. Natural Coastal Protection Series: Report 1. 
Cambridge Coastal Research Unit Working Paper 40 (2012) ISSN 2050-7941.

6. M. Lutfi, R. S. Afifah, B. Sulaiman, Risna. Indian J. of Sci. and Tech, 10, 29 (2017). Doi: 10.17485/ijst/2017/v10i29/116502

7. T. James, V. J. Savin, P. M. Claire, R. Md. Masumur, T. Arnel, M. Lutfi. J. of IDEC, 19, 3 (2013) pp. 131145. Doi: http://doi.org/10.15027/35045

8. L. S. Hamilton, S. C. Snedaker. Handbook for mangrove area management. Honolulu: East-West Environment and Policy Institute. (1984)

9. R. Dahuri, J. Rais, S. P. Ginting, M. J. Sitepu, Pengelolaan sumberdaya wilayah pesisir dan lautan secara terpadu. Pradnya Paramita, Jakarta, (1996).

10. C. Giri, E. Ochieng, L. L. Tieszen, Z. Zhu, A. Singh, T. Loveland, N. Duke. (2011). Global Ecology and Biogeography, 20, 1, pp. 154-159.

11. C. Kuenzer, M. Ottinger, M. Wegmann, H. Guo, C. Wang, J. Zhang, M. Wikelski. International Journal of Remote Sensing, 35, 18 (2014) 6599-6647.

12. C. Kuenzer, M. Ottinger, M. Wegmann, H. Guo, C. Wang, J. Zhang, M. Wikelski. International Journal of Remote Sensing, 35, 18 (2014) 6599-6647.
13. M. Boer, N. T. Pratiwi. J. Ilmu dan Teknologi Kelautan Tropis, 7, 2 (2016).

14. H. Masood, S. Afsar, U. B. Zamir, J. H. Kazmi. Application of Comparative Remote Sensing Techniques for Monitoring Mangroves in Indus Delta, Sindh, Pakistan. In Biological Forum 7, 1 (2015), p. 783.

15. B. C. Adeleke, T. Nzama, Assessment of community participation in ecotourism and conservation at Hhuhuwe-Umfolozi Park, South Africa. Journal of Environment and Earth Science. (2013)

16. J. A. Robinson, K. P. Lulla, M. Kashiwagi, M. Suzuki, M. D. Nellis, C. E. Bussing, L. J. McKenzie. Conservation Biology, 15, 4 (2001), pp. 876-884.

17. C. J. León, J. de León, J. E. Araña. M. M. González. Ecological Economics, 118 (2015) pp. 21-29.

18. Rudi Sanjaya, https://www.academia.edu/3304700/Jenis__Jenis_Alat_Tangkap_Ikan_dan_Pengoperasiannya

19. C. G. Sevilla, Research Methods. Rex Bookstore, Inc. (1992) 